Article

\title{
The Impact of Injector Hole Diameter on Spray Behaviour for Butanol-Diesel Blends
}

\author{
Sattar Jabbar Murad Algayyim ${ }^{1,2, *}$, Andrew P. Wandel ${ }^{1}$ (i) and Talal Yusaf ${ }^{1}$ \\ 1 School of Mechanical and Electrical Engineering, University of Southern Queensland, Toowoomba 4350, \\ QLD, Australia; andrew.wandel@usq.edu.au (A.P.W.); Talal.Yusaf@usq.edu.au (T.Y.) \\ 2 Department of Mechanical, College of Engineering, University of Al-Qadisiyah, Al-Diwaniyah 58001, Iraq \\ * Correspondence: sattarjabbarmurad.algayyim@usq.edu.au or ialiraq12@yahoo.com; Tel.: +61-431-291-580
}

Received: 6 April 2018; Accepted: 10 May 2018; Published: 19 May 2018

\begin{abstract}
Optimising the combustion process in compression ignition (CI) engines is of interest in current research as a potential means to reduce fuel consumption and emission levels. Combustion optimisation can be achieved as a result of understanding the relationship between spraying technique and combustion characteristics. Understanding macroscopic characteristics of spray is an important step in predicting combustion behaviour. This study investigates the impact of injector hole diameter on macroscopic spray characteristics (spray penetration, spray cone angle, and spray volume) of butanol-diesel blends. In the current study, a Bosch $(0.18 \mathrm{~mm}$ diameter $)$ and a Delphi $(0.198 \mathrm{~mm})$ injector were used. Spray tests were carried out in a constant volume vessel (CVV) under different injection conditions. The test blends were injected using a solenoid injector with a common rail injection system and images captured using a high-speed camera. The experimental results showed that the spray penetration $(S)$ was increased with larger hole diameter. Spray penetration of a $20 \%$ butanol- $80 \%$ diesel blend was slightly further than that of neat diesel. Spray penetration of all test fuels was increased as a result of increased injection pressure (IP), while spray cone angle $(\theta)$ was slightly widened due to the increase in either hole diameter or injection pressure. Spray volume of all test fuels was increased as a result of increased hole diameter or injection pressure. Thus, an efficient diesel engine performance can be achieved as a result of controlling injection characteristics, especially when using a promising additive like butanol blended with diesel.
\end{abstract}

Keywords: butanol; spray characteristics; injector hole diameter; visualisation

\section{Introduction}

As a response to the high demand for environmental security, more attention is being paid to utilising fuels with lower emissions and optimising combustion processes [1-8]. Optimising the combustion process in compression ignition (CI) engines has been employed in the current study because this can reduce fuel consumption and pollutants [9-13]. Combustion optimisation can be achieved through an understanding of spray behaviour in CI engines [13]. CI engines' performance and emissions are very sensitive to fuel spray behaviour (controlled by the nozzle geometry; the nozzle position in engine cylinder; and the injection method, such as direct injection or dual injection), which influence fuel-air surface area contact and mixing rate. Visualisation techniques are sometimes applied in engine configurations with optical access $[14,15]$ (using either a modified or a specially-built engine). Alternatively, a constant volume vessel (CVV) can be used at either similar conditions to real engines [16-19] or at atmospheric conditions [20,21] because design and fabrication of an engine with an optical window is a costly and complex option [22-24].

Another mechanism to reduce environmental impact is to utilise one of the growing number of alternative fuels such as alcohols [1-3] or biodiesel [25]. This has led to increased and accelerated 
interest in studying the relationship between spray techniques and combustion characteristics of these fuels [21]. Butanol has become an important alternative fuel for $\mathrm{CI}$ engines in recent years due to its eco-friendly production method $[2,26]$. It also has favourable physicochemical properties compared to ethanol [1,27-34]: it is less hygroscopic, reducing corrosion in the fuel injection system [27]; and it is safer in fuel tanks and storage because of its higher flash point. Furthermore, the lower viscosity, higher laminar flame speed and oxygen content of butanol [28,30] compared to neat diesel result in an enhanced atomization, vaporization and reaction rate, which produce emissions (such as soot, smoke, $\mathrm{NO}_{x}$ and $\mathrm{CO}$ ) reductions $\mathrm{CI}$ engines [29-34].

Some previous studies have investigated the impact of butanol as an additive on characteristic spray behaviour. Liu et al. [35] compared the effects of $20 \%$ ethanol and $20 \%$ butanol as additives in 80\% soybean biodiesel fuel (B20S80 and E20S80, respectively) using a CVV at different ambient temperatures from 800 to $1200 \mathrm{~K}$. Both ethanol and butanol blends enhance the spray behaviour of biodiesel due to improving biodiesel properties such as viscosity and surface tension. Wu et al. [36] examined the effect of $n$-butanol (B) and an acetone-butanol-ethanol (ABE) mixture on spray behaviour under different temperatures and oxygen content in a CVV. The images of the experimental results showed that liquid penetrations of $B$ and the ABE mixture were much shorter than that of neat diesel under high ambient temperatures. Both neat $B$ and $A B E$ have a lower boiling point, lower viscosity and higher vapour pressure compared to neat diesel, which improves the vaporisation and atomisation rate. Rao et al. [37] investigated the droplets fragmentation behaviour of three blend ratios $(10 \%, 30 \%$ and $50 \%$ ) of $\mathrm{B}$ and $\mathrm{ABE}$ blended with jet A-1 fuel. The fragmentation of droplets plays a major factor in increasing atomization and vaporization rate, which can lead to efficient combustion. Algayyim et al. [8] experimentally and numerically investigated macroscopic and microscopic spray characteristics of butanol-diesel blends under different ambient conditions. They found that a butanol blend can enhance spray characteristics such as spray tip penetration.

Spray parameters are also affected by spray injection pressure and injector geometry (hole diameter, number of holes, and spray angle). A higher injection pressure (IP) enhances the interaction between ambient gases and droplets as a result of higher kinetic energy [12,22,38]. The turbulent and cavitation characteristics of an injector can be directly affected by the nozzle geometry and position [11,39-41]. Moon et al. [41] investigated the effect of the number $(1,3$ and 6) nozzle holes with nozzle hole diameter $0.12 \mathrm{~mm}$ on the dynamic characteristics of diesel injection. They found that the multi-hole injector significantly alters the flow patterns of the injected fuel compared to the single-hole injector, which results in more mixing rate between injected fuel and available air.

Some research has been conducted into the spray characteristics resulting from realistic diesel multi-hole nozzles with different hole diameters [42,43]. Mulemane et al. [42] experimentally and numerically investigated the effect of injection pressure and injector hole diameter on injection rate and, consequently, spray characteristics. Lai et al. [43] also experimentally studied the impact of the injector geometry features such as nozzle shape, needle lift, and injection pressure on fuel spray characteristics, with the spray behaviour near the nozzle tip strongly dependent on nozzle geometry. Kuti et al. [44] examined the effect of two injection hole diameters $(0.08$ and $0.16 \mathrm{~mm})$ on spray evaporation of neat biodiesel and neat conventional diesel under $100 \mathrm{MPa}$ and $300 \mathrm{MPa}$ injection pressures. The experimental results showed that the ignition region was bigger for the larger hole diameter, while it was smaller as a result of increased injection pressure.

This work expands current knowledge by investigating the impact of injector hole diameter and injection pressure on spray penetration, spray cone angle and spray volume of butanol-diesel blends.

\section{Fuel Preparation and Properties}

Analytical grade normal butanol (B, 99.8\%) supplied from Chem Supply Australia (Adelaide, Australia) was used. Conventional diesel supplied from a local Caltex petrol station in Toowoomba (Australia) was used as a baseline. $20 \%$ butanol (B) was blended with $80 \%$ neat diesel, referred to as B20D80. The density was measured for all test fuel blends according to ASTM 1298 [3]. The dynamic 
viscosities of the test fuels were measured according to the ASTM 445-01 [1] fuel standards by using a Brookfield Viscometer (DV-II+Pro Extra, AMETEK Brookfield, Middleboro, MA, USA); then the kinematic viscosity was subsequently calculated. The calorific values of the test blends were measured using a digital oxygen bomb calorimeter (XRY-1A, Shanghai Changji Geological Instrument Co., Ltd., Shanghai, China) following ASTM D240 [1,3]. Fuel properties of the test fuel blends are listed in Table 1.

Table 1. Properties of the test fuel blends.

\begin{tabular}{cccc}
\hline Properties & Diesel (D) & Butanol (B) & B20D80 \\
\hline Chemical formula & $\mathrm{C}_{12}-\mathrm{C}_{25}$ & $\mathrm{C}_{4} \mathrm{H}_{9} \mathrm{OH}$ & - \\
Composition $(\mathrm{C}, \mathrm{H}, \mathrm{O})($ mass $\%)$ & - & $65,13.5,21.5$ & - \\
Density $(\mathrm{kg} / \mathrm{L})$ & $0.86^{\mathrm{a}}$ & $0.810^{\mathrm{b}}$ & $0.825^{\mathrm{a}}$ \\
Viscosity $\left(\mathrm{mm}^{2} / \mathrm{s}\right)$ at $40^{\circ} \mathrm{C}$ & $2.46^{\mathrm{a}}$ & $2.2^{\mathrm{b}}$ & $2.25^{\mathrm{a}}$ \\
Calorific value $(\mathrm{MJ} / \mathrm{kg})$ & $42.65^{\mathrm{a}}$ & $33.1^{\mathrm{b}}$ & $41.17^{\mathrm{a}}$ \\
Surface tension $(\mathrm{mN} / \mathrm{m})$ & $23.8^{\mathrm{b}}$ & $24.2^{\mathrm{b}}$ & - \\
Cetane number & $48^{\mathrm{b}}$ & $17-25^{\mathrm{b}}$ & - \\
Latent heat of vaporisation $(\mathrm{kJ} / \mathrm{kg})$ & $270^{\mathrm{b}}$ & $582^{\mathrm{b}}$ & - \\
Boiling point $\left({ }^{\circ} \mathrm{C}\right)$ & $200-400^{\mathrm{b}}$ & $118^{\mathrm{b}}$ & - \\
Flash point $\left({ }^{\circ} \mathrm{C}\right)$ & $74^{\mathrm{b}}$ & $35^{\mathrm{b}}$ & - \\
\hline a: Properties are measured; ${ }^{\mathrm{b}}$ : Properties are from [1,2].
\end{tabular}

\section{Experimental Setup and Procedure}

\subsection{Spray Test Setup}

Figures 1 and 2 show the schematic of the experimental system setup. A high-pressure common-rail injection system was used to inject the test fuels into the CVV through a solenoid 6-hole injector, either a Bosch injector (part\#: 0445110 107, Robert Bosch, Gerlingen, Germany) with $0.18 \mathrm{~mm}$ diameter holes or a Delphi injector (SH0.135/SH0.096, Delphi Technologies, Troy, MI, USA) with $0.198 \mathrm{~mm}$ diameter holes. Both injectors have the same enclosed angle $\left(156^{\circ}\right)$ which means the identical characteristics of both injectors was employed except orifice diameter. Figure 3 shows the solenoid injector diagram including the hole diameter of both the Bosch and Delphi injectors. More detailed specifications of the injectors, visual data acquisition system and injection setup are listed in Table 2.

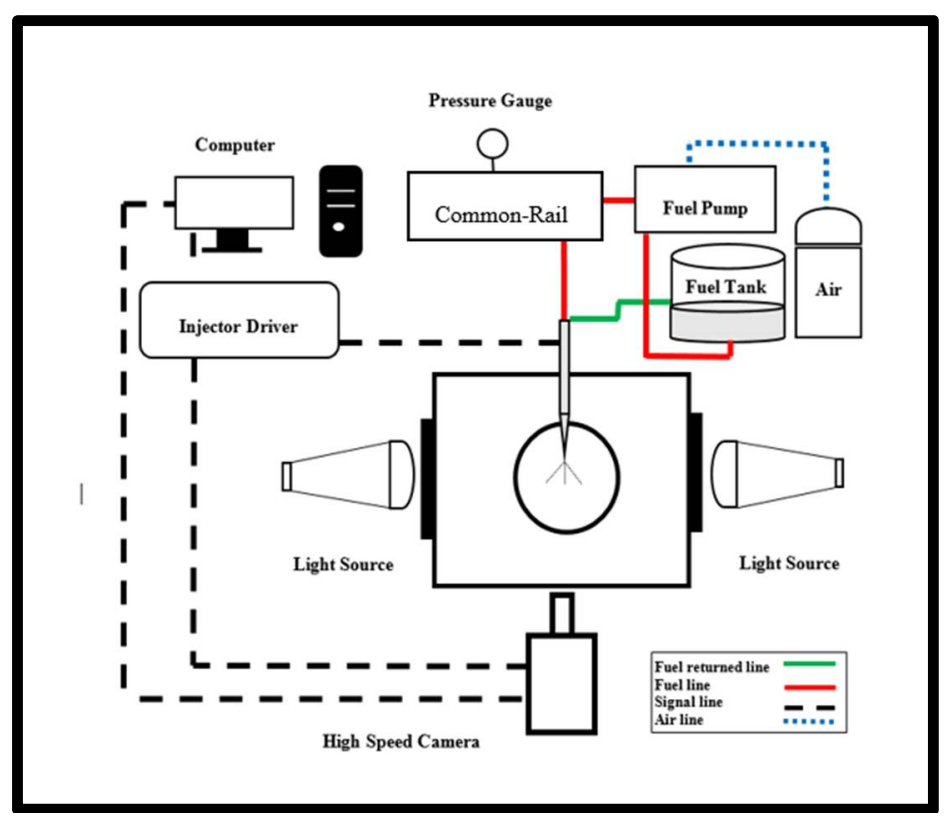

Figure 1. Schematic of the constant volume vessel with common rail fuel injection system setup, light source and visual data acquisition system. 


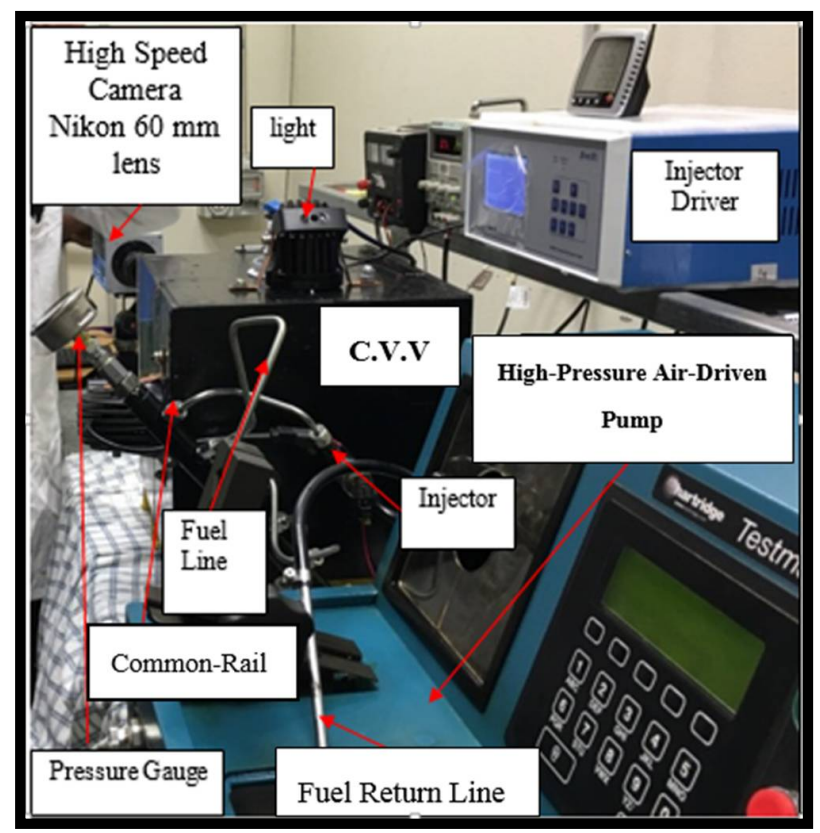

Figure 2. Experimental setup.

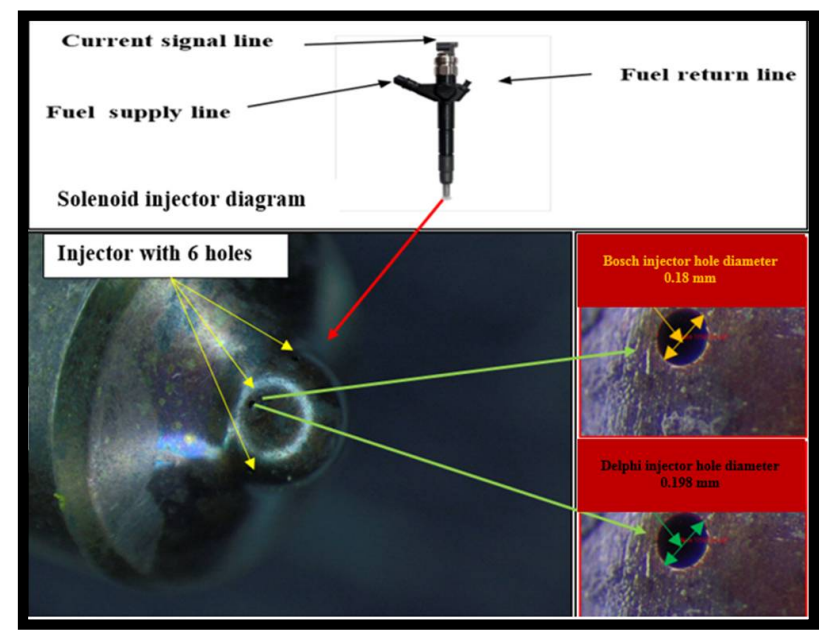

Figure 3. Solenoid injector diagram including hole diameter of Bosch and Delphi injectors.

Table 2. Specifications of the injector, high-speed camera and injection setup.

\begin{tabular}{|c|c|}
\hline & Injector Make/Type \\
\hline \multirow{2}{*}{ Injector type } & Bosch electromagnetic common rail solenoid injector (hole diameter $0.18 \mathrm{~mm}$ ) \\
\hline & Delphi electromagnetic common rail solenoid injector (hole diameter $0.198 \mathrm{~mm}$ ) \\
\hline Injection enclosed angle & $156^{\circ}$ \\
\hline Number of injector holes & 6 \\
\hline Injection quantity & $12 \mathrm{mg}$ \\
\hline \multicolumn{2}{|r|}{ Camera Specification and Filter } \\
\hline $\begin{array}{c}\text { Camera resolution at frame rate } \\
\text { Filter size }\end{array}$ & $\begin{array}{l}1024 \times 1024 \text { pixels at } 2000 \mathrm{fps} \\
62 \mathrm{~mm}\end{array}$ \\
\hline \multicolumn{2}{|r|}{ Injection Setup } \\
\hline Injection pressure & $300 \& 500$ bar \\
\hline After start of injection time (ASOI) & $0.5,0.75,1$ and $1.5 \mathrm{~ms}$ \\
\hline Fuel temperature & $21.5^{\circ} \mathrm{C}$ \\
\hline Room temperature & $22.8^{\circ} \mathrm{C}$ \\
\hline
\end{tabular}


A SA3 high-speed camera (Photron, Tokyo, Japan) with a resolution of $1024 \times 1024$ pixels, connected with a Nikon lens (Nikon Corporation, Tokyo, Japan) and filter size $62 \mathrm{~mm}$, was used to capture the images of the spray test blends. The shutter speed and frame rate were fixed at 1/2000 frames per second (fps). The CVV was using LED light on each of three windows.

\subsection{Spray Test Conditions}

The injection quantity was measured by injecting fuel 50 times from a measuring cylinder with the weight of the cylinder measured before and after the 50 injections for each injector. The spray characteristics of the B20D80 blend was investigated and compared to those of neat diesel as a baseline. The amount of butanol in the fuel was limited to $20 \%$ in this study so that the diesel engine did not require any modifications. The tests were carried out at atmospheric conditions at the conditions listed in Table 2 in triplicate to ensure accurate results. First, the fuel tank was emptied, cleaned and dried by air compressor for each new blend test. Then the fuel injection system (including common rail and fuel line fittings) were also emptied, cleaned and dried. Furthermore, the fuel filter from each test was removed and replaced with a new one and the spray testing started with a number of initial injections before the new images were captured. Finally, for each spray test, three shots were conducted, with the six plumes for all shots averaged to calculate the spray characteristics. The same elapsed time, injection pressure, and injection environment conditions were maintained for each injector to obtain a good, accurate comparative.

The image processing flow chart is displayed in Figure 4. The images were processed in three steps to enable quantification of the spray characteristics using a similar method to $[2,44,45]$. Firstly, the images were read in MATLAB (R2015b, The MathWorks, Inc., Natick, MA, USA), then converted into binary images to subtract the initial image thereby removing background effects. An automatic threshold calculation algorithm was employed to determine the spray outline (edge) from the binary images. Finally, the boundary pixels of each spray plume were identified so the spray characteristics (spray penetration, $S$, and spray cone angle, $\theta$, Figure 5) could be quantified from the spray contour. The fuel spray is assumed to be a cone with a hemisphere $[2,46,47]$ and the spray volume $\left(V\right.$ in $\left.\mathrm{mm}^{3}\right)$ is calculated by $[44,45]$ :

$$
V=\left(\frac{\pi}{3}\right) S^{3}\left[\tan ^{2}(\theta)\right] \frac{1+2 \tan \left(\frac{\theta}{2}\right)}{\left[1+\tan \left(\frac{\theta}{2}\right)\right]^{3}}
$$

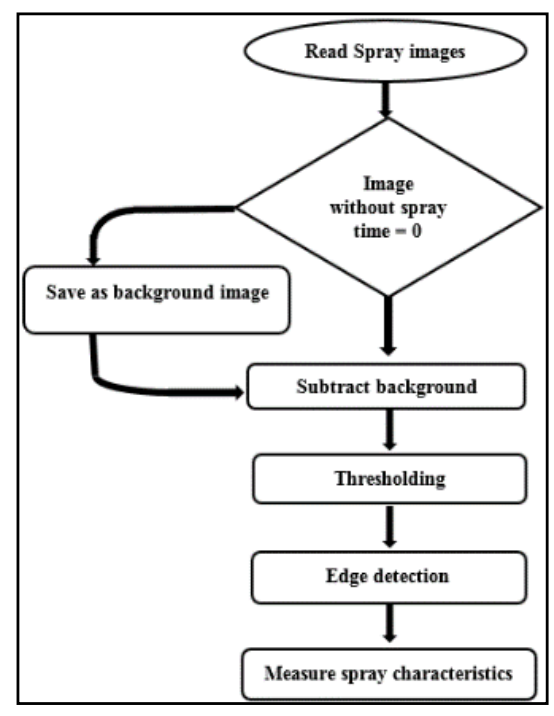

Figure 4. Image processing flowchart. 

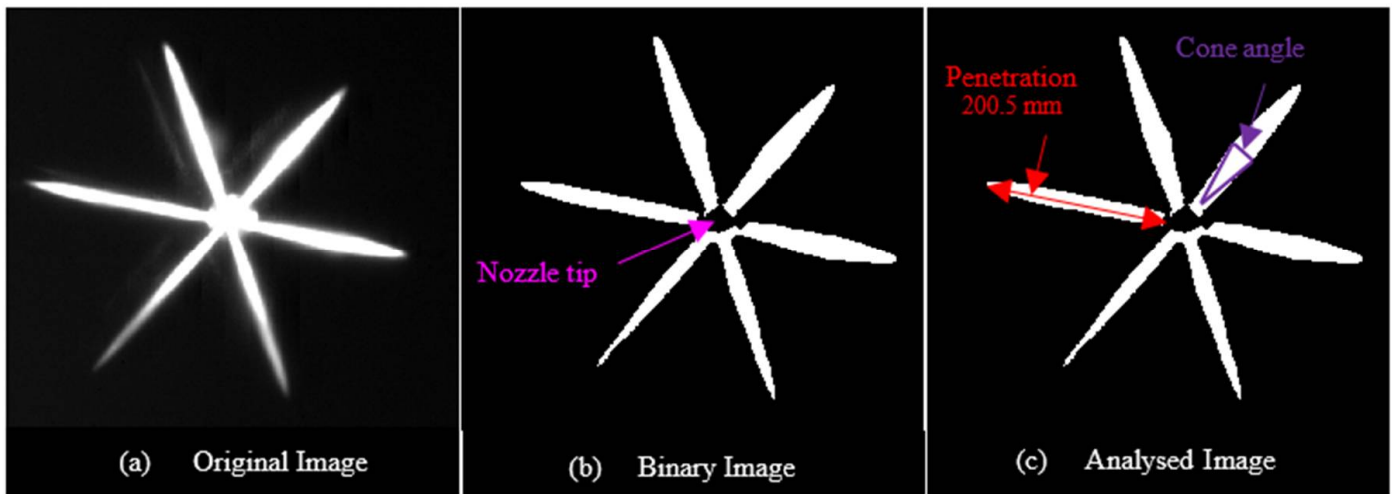

Figure 5. Spray image processing methodology, and spray penetration and spray cone angle definitions.

(a) Original Image; (b) Binary Image; (c) Analysed Image.

\section{Results of Spray Characteristics and Discussion}

\subsection{Spray Tip Penetration (S)}

The spray evolution and development of all test fuels under all conditions are displayed in Figure 6. These images are samples of triplicate tests. The left side of the figure shows images using the Bosch injector with a hole diameter of $0.18 \mathrm{~mm}$ and the right side shows images using the Delphi injector with a hole diameter of $0.198 \mathrm{~mm}$ at two injection pressures (IP). Rows from top to bottom show ASOI. The scaling of spray images or spray pattern body became bigger as a result of increased injector hole diameter, ASOI and IP values. Also, the butanol-diesel blend showed some improvement in spray plumes. Spray images of conventional diesel fuel were used as a baseline. The spray characteristics were quantified from these images.

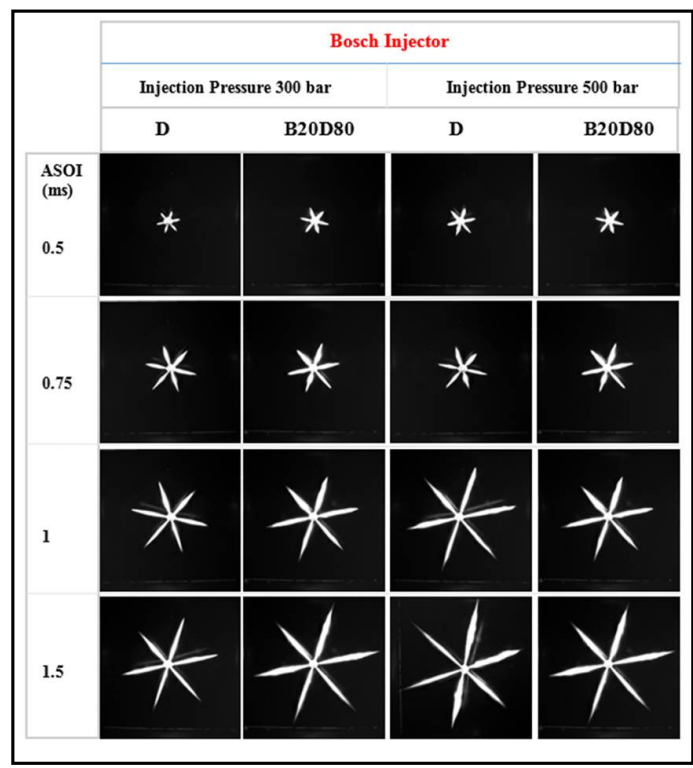

(a)

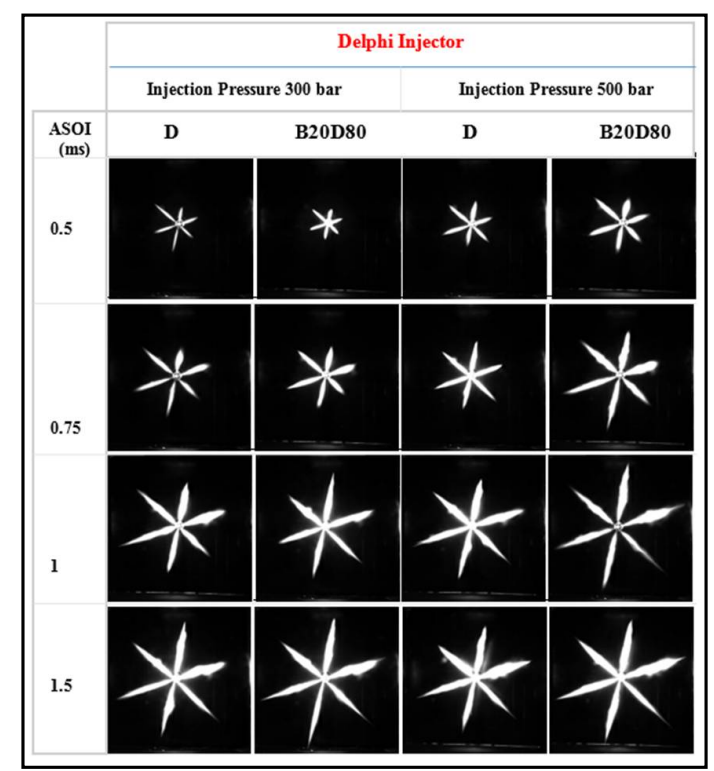

(b)

Figure 6. Spray images of test fuels using Bosch injector with hole diameter $0.18 \mathrm{~mm}$ (a) and Delphi injector with hole diameter $0.198 \mathrm{~mm}(\mathbf{b})$ at two injection pressures.

Figure 7 compares the effect of hole diameter on spray tip penetration of D and B20D80 blends. Spray tip penetration of the injector with a hole diameter of $0.198 \mathrm{~mm}$ produced higher spray tip penetration compared to the injector with a hole diameter of $0.18 \mathrm{~mm}$ at the same ASOI, injection pressures and fuel tests. Similar results were reported in $[44,45,48]$. Cavitation is increased 
as a result of increased injector hole diameter for internal flow [12], consequently increasing spray penetration. Longer penetration into $\mathrm{CI}$ engines together with high swirl ratio and hot walls result in more efficient combustion. However, sometimes (depending on the cylinder and piston geometries) high spray penetration causes unwanted fuel contact on the cylinder walls of compression ignition diesel engines, resulting in lower fuel/air mixing rates, which produces high emissions [49].

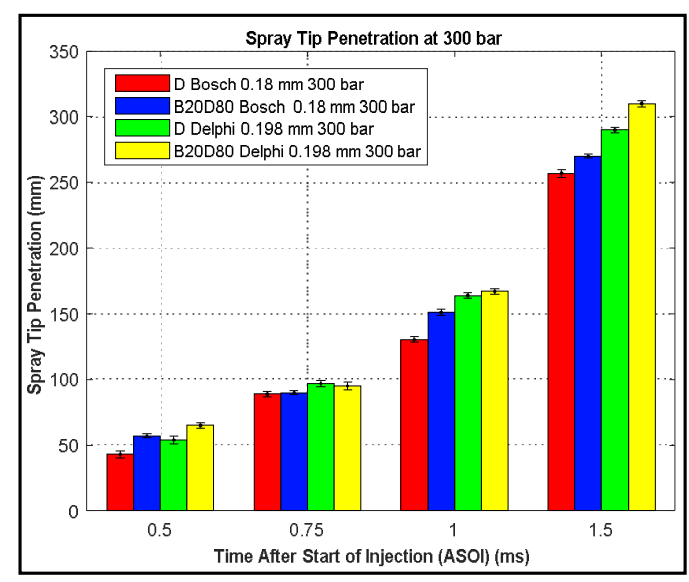

(a)

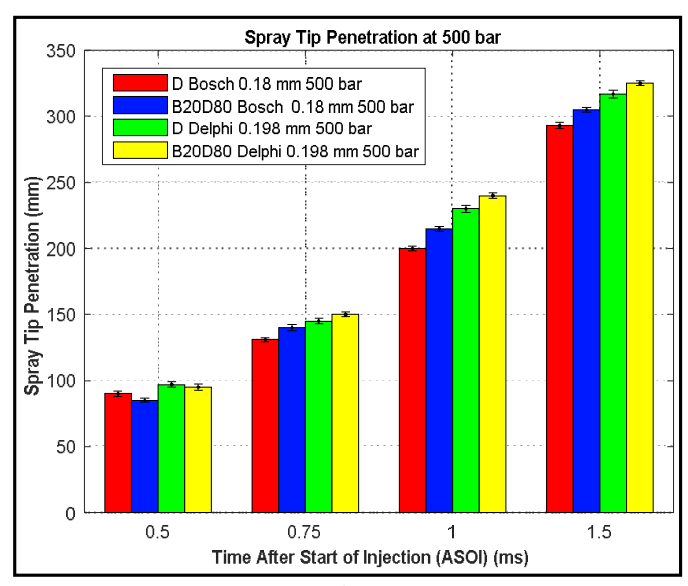

(b)

Figure 7. Spray tip penetration of test fuels for Bosch and Delphi injectors at two injection pressures. (a) Spray tip penetration at 300 bar; (b) Spray tip penetration at 500 bar.

Moreover, the injection velocity is reduced with increased hole diameter, which improves the spray break up and mixing rate. However, jet velocities which are too low cause the droplet size to become larger than the nozzle hole diameter because of surface wave fluctuations resulting from surface tension effects, reducing the spray atomisation rate and evaporation speed [12]. Therefore, there is insufficient time to complete the reaction. A high spray velocity is beneficial because it leads to early breakup in the atomisation regime of the nozzle jet, thereby creating smaller spray droplets than the injector's hole diameter.

Spray penetration of B20D80 blend shows a slightly higher value compared to that of neat diesel because the butanol content enhances the diesel properties (viscosity and surface tension), which result in high injection velocity and reduced nozzle loss. Spray tip penetration of test fuel under 500 bar injection pressure also became longer compared to 300 bar injection pressure (Figure 8) because of the higher kinetic energy [12,22]. These results are in agreement with the results reported in $[42,49]$.

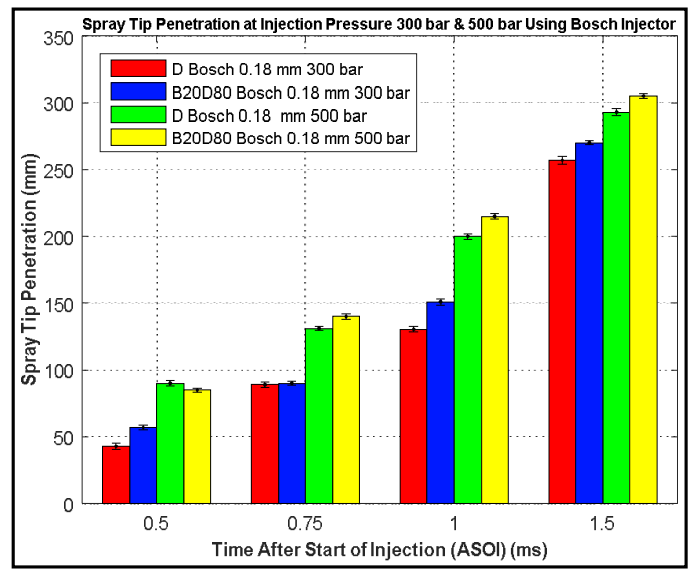

(a)

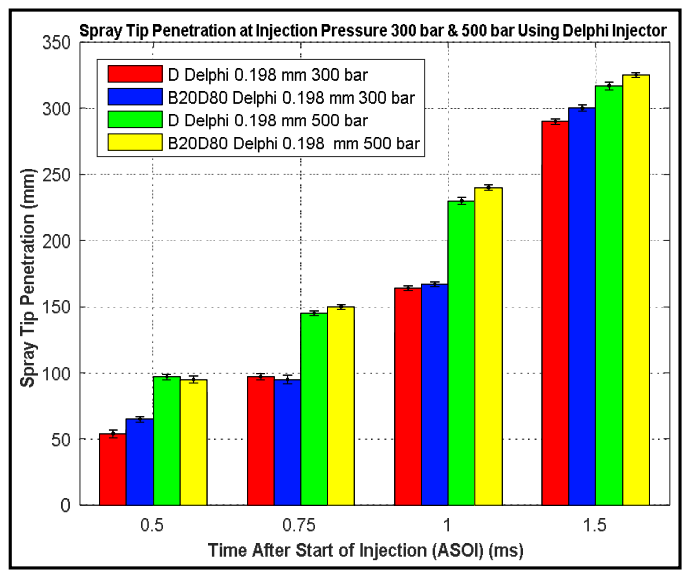

(b)

Figure 8. Effect of injection pressures (300 to 500 bar) on spray tip penetration of test fuels of Bosch injector (a) and Delphi injector (b). 


\subsection{Spray Cone Angle ( $\theta$ )}

The spray cone angle of the test blends is presented in Figure 9 at two injection pressures for the two different injectors. The spray cone angle was slightly widened for the larger hole diameter (Figure 9), while it was slightly narrowed for the higher injection pressure (Figure 10). Moreover, the spray cone angle was slightly changed for the butanol-diesel blend. Because of the greater uncertainty in determining spray cone angle, it can be stated that there is no significant impact of injector hole diameter, injection pressure and fuel type. However, when there is an insufficient radial momentum to overcome penetration resistance and the pressure difference across the sheet, then spray shoulders become strongly curved. The result was consistent with findings in $[1,49]$.

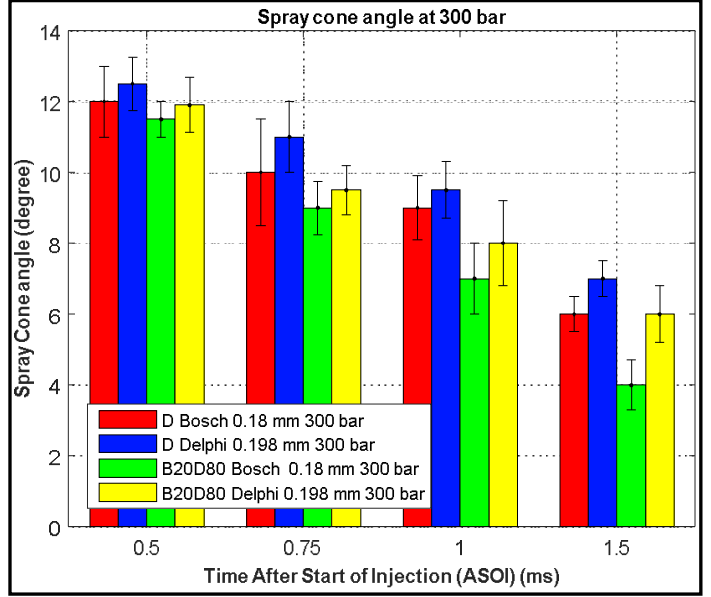

(a)

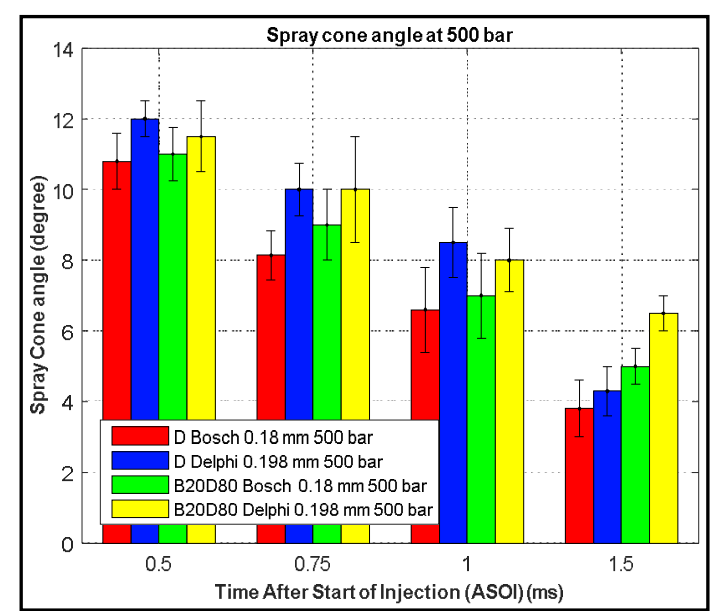

(b)

Figure 9. Comparative of effect of two injectors on spray cone angle of test fuel blends. (a) Spray cone angle at 300 bar; (b) Spray cone angle at 500 bar.

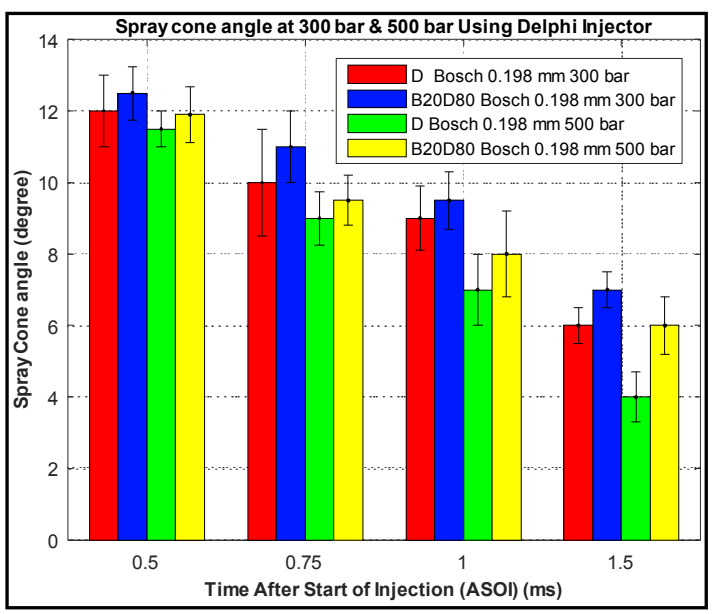

(a)

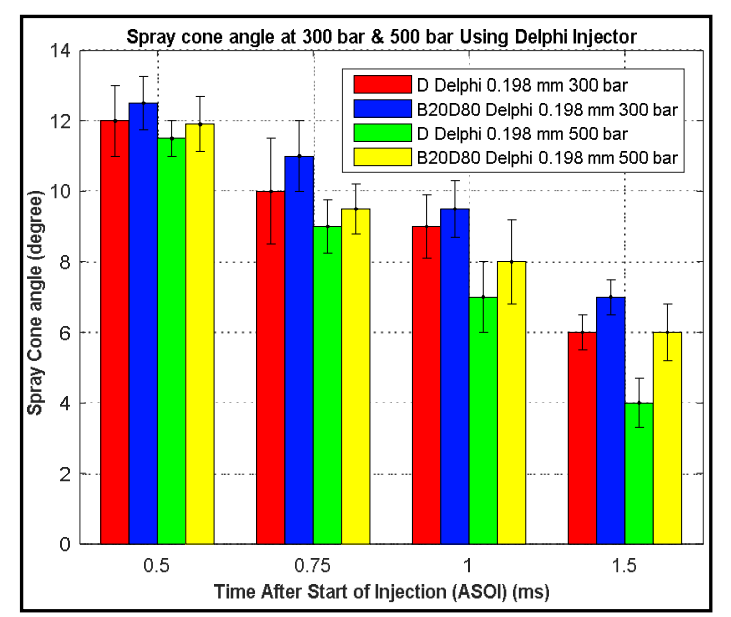

(b)

Figure 10. Comparative of effect of two injection pressures on spray cone angle of test fuel blends of Bosch injector (a) and Delphi (b).

\subsection{Spray Volume}

The spray volume of the test blends is presented in Figure 11 at two injection pressures for the two different injectors. The fuel spray is assumed to be a cone and hemisphere and the spray volume $(V)$ was calculated using Equation 1 for different injection conditions. The spray volume of the test fuel blends increased with larger injector hole diameter or injection pressure because of increased spray penetration. The spray volume of neat diesel was the smallest due to smaller spray 
penetration and spray cone angle, while the spray volume of the butanol-diesel blend was larger than neat diesel. The spray volume is mainly calculated by the spray penetration length, since the spray cone angles variation among different fuels is not significant, according to these results in Figure 11. Therefore, the contact surface area between the air and fuel would be increased, thereby resulting in increased mixing and reaction rates.

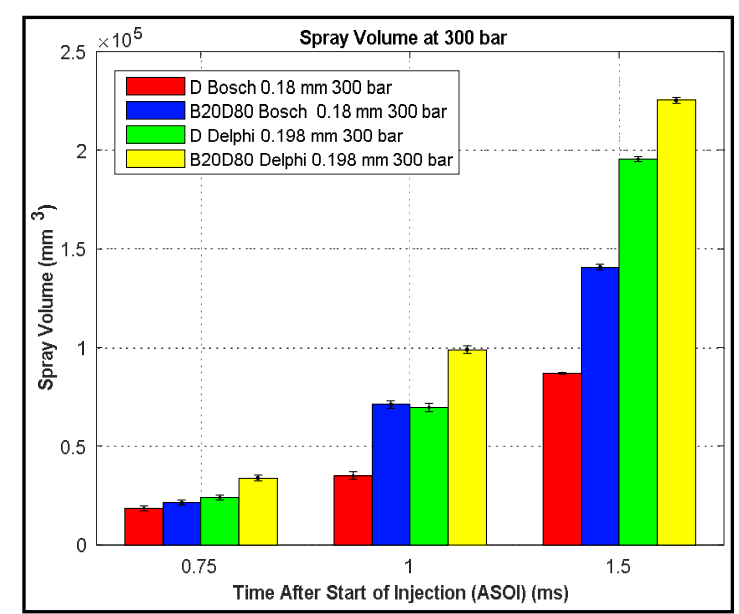

(a)

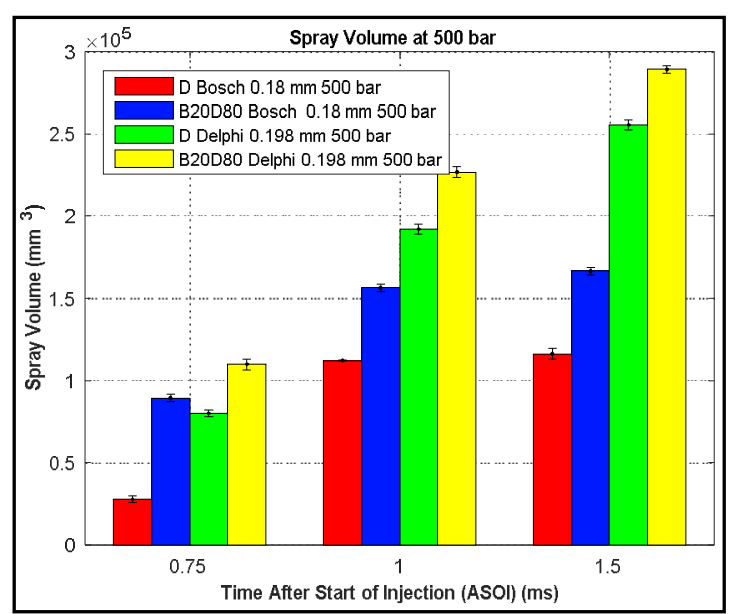

(b)

Figure 11. Spray volume of test fuels for Bosch and Delphi injectors at two injection pressures. (a) Spray volume at 300 bar; (b) Spray volume at 500 bar.

\section{Conclusions}

The experiments studied here revealed the behaviour of the test fuel blends relating to spray evaluation. The spray test was carried out in a constant volume vessel using two multiple hole injectors (hole diameters of $0.18 \mathrm{~mm}$ and $0.198 \mathrm{~mm}$ ). The spray images of the test fuel blends were captured using a high-speed camera and then spray characteristics were measured. Some conclusions follow:

* The spray images evaluation showed that the spray penetration length was increased with larger hole diameter and high injection pressure. The spray penetration of the B20D80 blend was slightly further than neat diesel because the butanol reduces the viscosity.

* The spray penetration of the test fuel blends becomes longer while the spray cone angle was slightly widened via the increase in either injection pressure or hole diameter.

* The spray volume of all the test fuels was increased as a result of increased hole diameter or injection pressures, which results in increased contact surface area between air and fuel, thereby resulting in increased mixing rate and combustion efficiency.

In conclusion, controlling injection characteristics of the injector in compression ignition (CI) engines could lead to more efficient mixing between the injected fuel and spray propagation. Thus, additional advantages can be gained to achieve an efficient diesel engine performance, especially when using promising alternative fuels like butanol blended with diesel.

Author Contributions: S.J.M.A., A.P.W. and T.Y. conceived and designed the experiments; S.J.M.A. performed the experiments; S.J.M.A. and A.P.W. analyzed the data. S.J.M.A. wrote the paper; and A.P.W. and T.Y. provided major editorial contribution and guidance.

Acknowledgments: The first author thanks the Iraqi Government Ministry of Higher Education and Scientific Research for supporting the research. The authors are also grateful to Rishabh Choudhury for his assistance with the spray experiments and Daniel McIntyre from Diesel Care Australia Pty Ltd., Toowoomba branch, for his discussion and advice related to the common rail injection system.

Conflicts of Interest: The authors declare no conflict of interest. 


\section{References}

1. Algayyim, S.J.M.; Wandel, A.P.; Yusaf, T.; Hamawand, I. The impact of n-butanol and iso-butanol as components of butanol-acetone (BA) mixture-diesel blend on spray, combustion characteristics, engine performance and emission in direct injection diesel engine. Energy 2017, 140 Pt 1, 1074-1086. [CrossRef]

2. Algayyim, S.J.M.; Wandel, A.P.; Yusaf, T.; Hamawand, I. Production and application of ABE as a biofuel. Renew. Sustain. Energy Rev. 2018, 82 Pt 1, 1195-1214. [CrossRef]

3. Algayyim, S.J.M.; Wandel, A.P.; Yusaf, T.; Al-Lwayzy, S.; Hamawand, I. Impact of butanol-acetone mixture as a fuel additive on diesel engine performance and emissions. Fuel 2018, 227, 118-126. [CrossRef]

4. Algayyim, S.J.M.; Wandel, A.P.; Yusaf, T.; Hamawand, I.; AL-Lwayzy, S. The Experimental Investigation of Butanol-Diesel Blend on Engine Performance and Emission Levels in DI Diesel Engine. In Proceedings of the 1st MoHESR and HCED Iraq Scholars Conference in Australasia 2017 (ISCA 2017), Melbourne, Australia, 5-6 December 2017; Swinburne University: Melbourne, Australia, 2017.

5. Algayyim, S.J.M.; Wandel, A.P.; Yusaf, T. The effect of Butanol-Acetone Mixture-Cottonseed Biodiesel Blend on Spray Characteristics, Engine Performance and Emissions in Diesel Engine. In Proceedings of the 11th Asia-Pacific Conference on Combustion, Sydney, Australia, 10-14 December 2017; The University of Sydney: Sydney, Australia, 2017.

6. Zaharin, M.S.M.; Abdullah, N.R.; Najafi, G.; Sharudin, H.; Yusaf, T. Effects of physicochemical properties of biodiesel fuel blends with alcohol on diesel engine performance and exhaust emissions: A review. Renew. Sustain. Energy Rev. 2017, 79, 475-493. [CrossRef]

7. Emiroğlu, A.O.; Şen, M. Combustion, performance and emission characteristics of various alcohol blends in a single cylinder diesel engine. Fuel 2018, 212, 34-40. [CrossRef]

8. Algayyim, S.J.M.; Wandel, A.P.; Yusaf, T. Experimental and Numerical Investigation of Spray Characteristics of Butanol-Diesel blends. In Proceedings of the 11th Asia-Pacific Conference on Combustion, Sydney, Australia, 10-14 December 2017; The University of Sydney: Sydney, Australia, 2017.

9. Shuai, C.; Shen, L.; Jiao, L.; Wu, Y.; Tan, Y. Identifying key impact factors on carbon emission: Evidences from panel and time-series data of 125 countries from 1990 to 2011. Appl. Energy 2017, 187, 310-325. [CrossRef]

10. Algayyim, S.J.M.; Wandel, A.; Yusaf, T.; Hamawand, I.; Al-Lwayzy, S. Experimental Study of Spray Characteristics, Engine Performance and Emission Levels of Acetone-Butanol-Ethanol Mixture-Diesel Blends in a Diesel Engine. In Proceedings of the 11th Asia-Pacific Conference on Combustion, Sydney, Australia, 10-14 December 2017; The University of Sydney: Sydney, Australia, 2017.

11. Lee, S.; Lee, C.S.; Park, S.; Gupta, J.G.; Maurya, R.K.; Agarwal, A.K. Spray characteristics, engine performance and emissions analysis for Karanja biodiesel and its blends. Energy 2017, 119, 138-151. [CrossRef]

12. Dong, P.; Yamauchi, J.; Nishida, K.; Ogata, Y. Hole Geometrical Effect on Internal Flow, Fuel Atomization and Spray Evaporation of Multi-Hole Nozzle for Diesel Engine; SAE Technical Paper; SAE International: Warrendale, PA, USA, 2017.

13. Suh, H.K.; Lee, C.S. A review on atomization and exhaust emissions of a biodiesel-fueled compression ignition engine. Renew. Sustain. Energy Rev. 2016, 58, 1601-1620. [CrossRef]

14. Soid, S.N.; Zainal, Z.A. Spray and combustion characterization for internal combustion engines using optical measuring techniques, A review. Energy 2011, 36, 724-741. [CrossRef]

15. Merola, S.S.; Marchitto, L.; Corcione, F.; Valentino, G.; Tornatore, C. Optical diagnostics of the pollutant formation in a CI engine operating with diesel fuel blends. SAE Int. J. Engines 2011, 4, 2543-2558. [CrossRef]

16. Huo, M.; Lin, S.; Liu, H.; Lee, C.-F.F. Study on the spray and combustion characteristics of water-emulsified diesel. Fuel 2014, 123, 218-229. [CrossRef]

17. Sazhin, S.S.; Feng, G.; Heikal, M.R. A model for fuel spray penetration. Fuel 2001, 80, 2171-2180. [CrossRef]

18. Wang, Z.; Wu, S.; Huang, Y.; Chen, Y.; Shi, S.; Cheng, X.; Huang, R. Evaporation and Ignition Characteristics of Water Emulsified Diesel under Conventional and Low Temperature Combustion Conditions. Energies 2017, 10, 1109. [CrossRef]

19. Zhang, X.; Li, T.; Ma, P.; Wang, B. Spray Combustion Characteristics and Soot Emission Reduction of Hydrous Ethanol Diesel Emulsion Fuel Using Color-Ratio Pyrometry. Energies 2017, 10, 2062. [CrossRef]

20. Verma, I.; Bish, E.; Kuntz, M.; Meeks, E.; Puduppakkam, K.; Naik, C.; Liang, L. CFD Modeling of Spark Ignited Gasoline Engines_-Part 2: Modeling the Engine in Direct Injection Mode along with Spray Validation; No. 2016-01-0579; SAE Technical Paper: Warrendale, PA, USA, 2016. 
21. Gupta, J.G.; Agarwal, A.K. Macroscopic and Microscopic Spray Characteristics of Diesel and Karanja Biodiesel Blends; No. 2016-01-0869; SAE Technical Paper: Warrendale, PA, USA, 2016. [CrossRef]

22. Todd, D.F.; Scott, E.P. Spray measurement technology: A review. Meas. Sci. Technol. 2015, 26, 012002.

23. Linne, M. Imaging in the optically dense regions of a spray: A review of developing techniques. Prog. Energy Combust. Sci. 2013, 39, 403-440. [CrossRef]

24. Chen, P.-C.; Wang, W.-C.; Roberts, W.L.; Fang, T. Spray and atomization of diesel fuel and its alternatives from a single-hole injector using a common rail fuel injection system. Fuel 2013, 103, 850-861. [CrossRef]

25. Ge, J.C.; Yoon, S.K.; Choi, N.J. Using Canola Oil Biodiesel as an Alternative Fuel in Diesel Engines: A Review. Appl. Sci. 2017, 7, 881. [CrossRef]

26. Kandasamy, M.; Hamawand, I.; Bowtell, L.; Seneweera, S.; Chakrabarty, S.; Yusaf, T.; Shakoor, Z.; Algayyim, S.J.M.; Eberhard, F. Investigation of Ethanol Production Potential from Lignocellulosic Material without Enzymatic Hydrolysis Using the Ultrasound Technique. Energies 2017, 10, 62. [CrossRef]

27. Trindade, W.R.D.S.; Santos, R.G.D. Review on the characteristics of butanol, its production and use as fuel in internal combustion engines. Renew. Sustain. Energy Rev. 2017, 69, 642-651. [CrossRef]

28. Rajesh Kumar, B.; Saravanan, S.; Rana, D.; Nagendran, A. A comparative analysis on combustion and emissions of some next generation higher-alcohol/diesel blends in a direct-injection diesel engine. Energy Convers. Manag. 2016, 119, 246-256. [CrossRef]

29. Armas, O.; García-Contreras, R.; Ramos, Á. Pollutant emissions from New European Driving Cycle with ethanol and butanol diesel blends. Fuel Process. Technol. 2014, 122, 64-71. [CrossRef]

30. Karabektas, M.; Hosoz, M. Performance and emission characteristics of a diesel engine using isobutanol-diesel fuel blends. Renew. Energy 2009, 34, 1554-1559. [CrossRef]

31. Doğan, $\mathrm{O}$. The influence of $\mathrm{n}$-butanol/diesel fuel blends utilization on a small diesel engine performance and emissions. Fuel 2011, 90, 2467-2472. [CrossRef]

32. Yao, M.; Wang, H.; Zheng, Z.; Yue, Y. Experimental study of n-butanol additive and multi-injection on HD diesel engine performance and emissions. Fuel 2010, 89, 2191-2201. [CrossRef]

33. Dobre, A.; Pană, C.; Nuţu, N.; Negurescu, N.; Cernat, A.; Bondoc, I. Bio-butanol-alternative fuel for Diesel engine. INMATEH-Agric. Eng. 2014, 42, 145-152.

34. Li, Q.; Jin, W.; Huang, Z. Laminar Flame Characteristics of C1-C5 Primary Alcohol-Isooctane Blends at Elevated Temperature. Energies 2016, 9, 511. [CrossRef]

35. Liu, H.; Lee, C.; Huo, M.; Yao, M. Comparison of ethanol and butanol as additives in soybean biodiesel using a constant volume combustion chamber. Energy Fuels 2011, 25, 1837-1846. [CrossRef]

36. Wu, H.; Nithyanandan, K.; Lee, T.H.; Lee, C.-F.F.; Zhang, C. Spray and combustion characteristics of neat acetone-butanol-ethanol, n-butanol, and diesel in a constant volume chamber. Energy Fuels 2014, 28, 6380-6391. [CrossRef]

37. Rao, D.C.K.; Karmakar, S.; Som, S.K. Puffing and Micro-Explosion Behavior in Combustion of Butanol/Jet A-1 and Acetone-Butanol-Ethanol (A-B-E)/Jet A-1 Fuel Droplets. Combust. Sci. Technol. 2017, 189, 1796-1812. [CrossRef]

38. Lešnik, L.; Vajda, B.; Žunič, Z.; Škerget, L.; Kegl, B. The influence of biodiesel fuel on injection characteristics, diesel engine performance, and emission formation. Appl. Energy 2013, 111, 558-570. [CrossRef]

39. Kang, S.; Cho, W.; Bae, C.; Kim, Y. Influence of the Injector Geometry at 250 MPa Injection in a Light-Duty Diesel Engine; SAE International: Warrendale, PA, USA, 2017.

40. Payri, R.; Salvador, F.J.; De la Morena, J.; Pagano, V. Experimental investigation of the effect of orifices inclination angle in multihole diesel injector nozzles. Part 2-Spray characteristics. Fuel 2018, 213, 215-221. [CrossRef]

41. Moon, S.; Gao, Y.; Park, S.; Wang, J.; Kurimoto, N.; Nishijima, Y. Effect of the number and position of nozzle holes on in-and near-nozzle dynamic characteristics of diesel injection. Fuel 2015, 150, 112-122. [CrossRef]

42. Mulemane, A.; Han, J.-S.; Lu, P.-H.; Yoon, S.-J.; Lai, M.-C. Modeling Dynamic Behavior of Diesel Fuel Injection Systems; No. 2004-01-0536; SAE Technical Paper: Warrendale, PA, USA, 2004. [CrossRef]

43. Lai, M.-C.; Wang, T.C.T.; Xie, X.; Han, J.-S.; Henein, N.; Schwarz, E.; Bryzik, W. Microscopic Characterization of Diesel Sprays at VCO Nozzle Exit; No. 982542; SAE Technical Paper: Warrendale, PA, USA, 1998. [CrossRef]

44. Kuti, O.A.; Zhu, J.; Nishida, K.; Wang, X.; Huang, Z. Characterization of spray and combustion processes of biodiesel fuel injected by diesel engine common rail system. Fuel 2013, 104, 838-846. [CrossRef]

45. Delacourt, E.; Desmet, B.; Besson, B. Characterisation of very high pressure diesel sprays using digital imaging techniques. Fuel 2005, 84, 859-867. [CrossRef] 
46. Yu, W.; Yang, W.; Mohan, B.; Tay, K.L.; Zhao, F. Macroscopic spray characteristics of wide distillation fuel (WDF). Appl. Energy 2017, 185, 1372-1382. [CrossRef]

47. Yu, W.; Yang, W.; Tay, K.; Mohan, B.; Zhao, F.; Zhang, Y. Macroscopic spray characteristics of kerosene and diesel based on two different piezoelectric and solenoid injectors. Exp. Therm. Fluid Sci. 2016, 76, 12-23. [CrossRef]

48. Wang, X.; Huang, Z.; Kuti, O.A.; Zhang, W.; Nishida, K. Experimental and analytical study on biodiesel and diesel spray characteristics under ultra-high injection pressure. Int. J. Heat Fluid Flow 2010, 31, 659-666. [CrossRef]

49. Heywood, J.B. Internal Combustion Engine Fundamentals; McGraw-Hill: New York, NY, USA, 1988.

(C) 2018 by the authors. Licensee MDPI, Basel, Switzerland. This article is an open access article distributed under the terms and conditions of the Creative Commons Attribution (CC BY) license (http:/ / creativecommons.org/licenses/by/4.0/). 